\title{
FIBRIN GEL AS A SCAFFOLD FOR SKIN SUBSTITUTE - PRODUCTION AND CLINICAL EXPERIENCE
}

\author{
Antun Kljenak ${ }^{1}$, Mirna Tominac Trcin², Marina Bujić2 ${ }^{2}$ Tamara Dolenec ${ }^{2}$, Martina Jevak2 \\ Gordan Mršićs ${ }^{3,4}$, Gordana Zmiš2 ${ }^{2}$ Zoran Barčot ${ }^{1}$, Ante Muljačićc ${ }^{2}$ and Maja Popovićc \\ ${ }^{1}$ Zagreb Children's Hospital; ${ }^{2}$ Tissue Bank, University Department of Traumatology, Sestre milosrdnice \\ University Hospital Center; ${ }^{3} I v a n$ Vučetić Center for Forensic Investigations, Research and Expertise; \\ ${ }^{4}$ Department of Biology, Faculty of Veterinary Medicine, University of Zagreb, Zagreb, Croatia
}

\begin{abstract}
SUMMARY - The purpose of this study was to create a fibrin-based human skin substitute in vitro with epidermal and dermal component and to assess its healing potential in deep partial and full thickness burns. Fibrin scaffolds were prepared from commercial fibrin glue kits. Human fibroblasts were cultured in fibrin gel. Human keratinocytes were seeded on the top of the gel. Viability of cells was determined fluorimetrically. Scanning electron microscope and immunocytochemistry analysis of cultured cells were performed. After hydrosurgical preparation of deep burn necrotic tissue, wound bed was prepared for skin substitutes. Progress of healing was documented using visual estimation and photos. Scanning electron microscope images showed good cell attachment and colony spreading of keratinocytes and fibroblasts on fibrin scaffold. Immunofluorescent staining of cell cultures on fibrin scaffold showed expression of vimentin, a marker of fibroblast cells, cytokeratin 19, a marker of epithelial stem cells, as well as involucrin, a marker of differentiated keratinocytes. Clinical results clearly showed that appearance of the skin did not differ significantly from the areas of transplanted skin using split-thickness skin graft techniques. In conclusion, using these fibrin-cultured autografts on massive full-thickness burn resulted in good healing.
\end{abstract}

Key words: Cells, cultured; Fibrin; Skin, artificial; Burns

\section{Introduction}

The treatment of burns becomes much more complicated when wounds are deep and extensive. When a burn has penetrated deeper into the dermis, skin regeneration relies only on stem cell reservoirs located in epithelial appendages such as hair follicles, sebaceous glands, and sweat glands ${ }^{1-4}$. When these reservoirs are destroyed, epithelialization can only start from wound margins. For deep partial and full thickness burns, necrotic tissue excision and wound closure with epidermal and partial dermal substitution is mandatory. The

Correspondence to: Mirna Tominac Trcin, PhD, MS, Tissue Bank, University Department of Traumatology, Sestre milosrdnice University Hospital Center, Draškovićeva 19, HR-10000 Zagreb, Croatia

E-mail: mirna.tomtrcin@gmail.com

Received April 14, 2015, accepted January 19, 2016 existence of dermal components is necessary for skin repair. At the end of the inflammation phase of the wound healing process, the first wave of fibroblasts $\mathrm{mi}^{-}$ grates from dermal margins to the wound bed attracted by local growth factors/cytokines. They start to proliferate and form granulation tissue. Fibronectin, collagen, hyaluronan, and other components of granulation tissue create a moist environment which facilitates further cell migration. In the proliferative and remodeling phases of healing, the keratinocyte-fibroblast interplay becomes dominant. Re-epithelialization starts as soon as granulation tissue fills an open wound; epithelial cells move over the surface of this provisional matrix, creating a barrier between the wound and the environment ${ }^{5}$. Studies of keratinocyte and fibroblast cocultures show that keratinocytes stimulate fibroblasts to synthesize growth factors, which in turn stimulate keratinocyte proliferation in a double paracrine 
manner. Both types of cells contribute to the synthesis of macromolecules of basement membrane. Fibroblasts produce collagen type IV and VII, laminin 5 , nidogen, and transforming growth factor beta (TGF- $\beta$ ), which in turn stimulates keratinocytes to synthesize collagen type IV and VII. Considering the importance of the keratinocyte-fibroblast interaction for the wound healing process, creating a complete skin equivalent with epidermal and dermal components has become a major focus of recent tissue engineering research ${ }^{6,7}$.

The choice of artificial extracellular matrix or scaffold is particularly important. It offers skin stem cells an optimal environment for in vitro growth and differentiation. Scaffolds for skin engineering must meet three basic criteria: patient safety, clinical efficacy, and convenience of use ${ }^{8}$. They should also have good mechanical and physical properties, controlled degradation rate, low immunogenicity, etc. ${ }^{9,10}$.

Fibrin as a natural, biodegradable polypeptide is involved in the initial phase of wound healing. The fibrin network provides a temporary scaffold which directs the early migration of fibroblasts and vascular endothelial cells into the wound bed ${ }^{11}$. Fibrin gel is frequently used in medicine as a tissue fixative. Over the last twenty years, it has been extensively studied in the tissue engineering field as a cell scaffold and as a material for delivering growth factors and genes to promote wound healing. Fibrin hydrogels could be prepared from commercial fibrin glue or from the patient's own plasma. They are used in tissue engineering of bone, skin, as well as cartilage, dental, cardiac and eye tissue $\mathrm{e}^{12,13}$. The utilization of fibrin gel in skin engineering started in 1988, with fibrin glue fixation of cultivated keratinocytes to the wound bed ${ }^{14}$. In several studies, burned patients were successfully treated with keratinocytes in fibrin gel ${ }^{15-17}$. Fibrin has also been used as a scaffold for cultivating dermal cell components. The presence of dermal fibroblasts in fibrin gel stimulated keratinocyte migration, increased the secretion of vascular endothelial growth factor (VEGF), improved regeneration of mature epidermal structure after in vivo transplantation, and promoted migration of vascular endothelial cells ${ }^{18-23}$.

The aim of our study was in vitro creation of a fibrin-based substitute with epidermal and dermal components. We tested the viability of human keratinocytes and fibroblasts grown in this fibrin matrix. This substitute was consequently applied to the burn areas of patients with deep partial and full thickness burns.

\section{Patients and Methods}

\section{Ethics}

Human skin samples were used upon approval granted by the Ethics Committee of the Clinical Department of Traumatology and having obtained informed consents from the patients.

\section{Cell isolation and culture}

For clinical application, upon Ethics Committee approval, human skin samples of approximately $2 \mathrm{~cm}^{2}$ were obtained from patient 1, a 14-year-old boy with electrocombustion and 65\% of Total Body Surface Area (TBSA) burns caused by high voltage, and from patient 2, a 5-year-old patient with combustion, 95\% TBSA burns caused by hot water. Burns were of depth degree IIb-III. Skin samples for cultivation were used from donor sites in non burned areas. In all other tests, skin cells from surgical surplus tissue were used. Cell isolation and culture were carried out under aseptic conditions in a clean room facility. Skin samples were washed in antibiotic-antimycotic solution (ABAM; Invitrogen, Carlsbad, California, USA) with amphotericin B $(2 \mathrm{~g} / \mathrm{mL})$, penicillin $(100 \mathrm{U} / \mathrm{mL})$ and streptomycin $(0.1 \mathrm{mg} / \mathrm{mL})$ and placed overnight at $4{ }^{\circ} \mathrm{C}$ in a solution of $4.4 \mathrm{mg} / \mathrm{mL}$ Dispase (Invitrogen, Carlsbad, California, USA) in phosphate buffered saline (PBS; Sigma Aldrich, St. Louis, Missouri, USA). The next day, the epidermis was peeled off from the dermis. Both skin parts were cut into small fragments. Dermal fragments were placed in Petri dish with fibroblast growth medium containing Dulbecco's Modified Eagle Medium (DMEM; Invitrogen, Carlsbad, California, USA), $10 \%$ of heat inactivated Australian Fetal Bovine Serum (FBS; Invitrogen Gibco, USA), ABAM (1\%) and 1\% L-glutamine (Invitrogen, Carlsbad, California, USA). Fibroblasts were cultured at $37{ }^{\circ} \mathrm{C}, 5 \%$ $\mathrm{CO}_{2}$ until $80 \%$ confluence. Afterwards, they were passaged. Fibroblasts from the second or third passage were used for all other experiments. Epidermal parts were incubated with $0.25 \%$ trypsin (Sigma Aldrich, St. Louis, Missouri, USA) at $37{ }^{\circ} \mathrm{C}$ for 30 minutes. Trypsin was neutralizated with keratinocyte growth medium containing 10\% FBS, 2:1 DMEM: Ham's 
F-12 (Invitrogen, Carlsbad, California, USA), 2\% Lglutamin, 1\% ABAM, $5 \mu \mathrm{g} / \mathrm{mL}$ insulin (Sigma Aldrich, St. Louis, Missouri, USA), $0.18 \mathrm{mM}$ adenine (Sigma Aldrich, St. Louis, Missouri, USA), $0.4 \mu \mathrm{g} / \mathrm{mL}$ hydrocortisone (Sigma Aldrich, St. Louis, Missouri, USA), $0.1 \mathrm{nM}$ cholera toxin (Accurate Chemicals \& Sicentific Corporation, New York, USA), 2 nM triiodothyronine (Sigma Aldrich, St. Louis, Missouri, USA) and $10 \mathrm{ng} / \mathrm{mL}$ epidermal growth factor (EGF) (Sigma Aldrich, St. Louis, Missouri, USA). Isolated cells were seeded at a 2:1 ratio on a lethally irradiated feeder layer of 3T3 cells. Culture medium was changed every third day. Cells were passaged at $80 \%$ of confluence. Keratinocytes from the second passage were used in all other procedures.

\section{Preparation of cultured epithelial autografts}

Cultured epithelial autografts (CEA) were prepared for clinical application according to the Rheinwald and Green method (Fig. 1a) ${ }^{24}$. Keratinocytes were cultured on a feeder layer of irradiated 3T3 cells at a 2:1 ratio in $75 \mathrm{~cm}^{2}$ tissue culture flasks until full confluence. On the day of grafting, epithelial sheets were detached with Dispase (Invitrogen, Carlsbad, California, USA) from tissue culture flasks and mounted on sterile silicon gauze (Mepitel, Mölnlycke Health Care AB, Gothenburg, Sweden). Sheets were washed and delivered to the operation room in serum free medium.

\section{Preparation of skin equivalent on fibrin scaffold}

Fibrin scaffolds were prepared aseptically from commercial $2 \mathrm{~mL}$ fibrin glue kits (Tisseel, Baxter AG, Vienna, Austria, EU) containing fibrinogen, aprotinin and thrombin components ${ }^{17}$. All components of the kit were kept in water bath at $37^{\circ} \mathrm{C}$ prior to manipulation. Fibrinogen powder was dissolved in $1 \mathrm{~mL}$ aprotinin and equal volume of solubilization saline containing $1.1 \% \mathrm{NaCl}$ and $1 \mathrm{mM} \mathrm{CaCl}_{2}$. Thrombin part was reconstituted with the same saline from $500 \mathrm{IU} /$ $\mathrm{mL}$ to $3 \mathrm{IU} / \mathrm{mL}$ and mixed, for clinical purpose, with human dermal fibroblasts, 20000 cells $/ \mathrm{cm}^{2}$ (Fig. 1b). Equal parts of thrombin and fibrinogen solution were added simultaneously with duploject application system into tissue culture vessels: $(\varnothing=90 \mathrm{~mm})$ Petri dishes or $75 \mathrm{~cm}^{2}$ flasks. In order to prevent strong gluing of the fibrin scaffold to the surface of the vessel, caused by
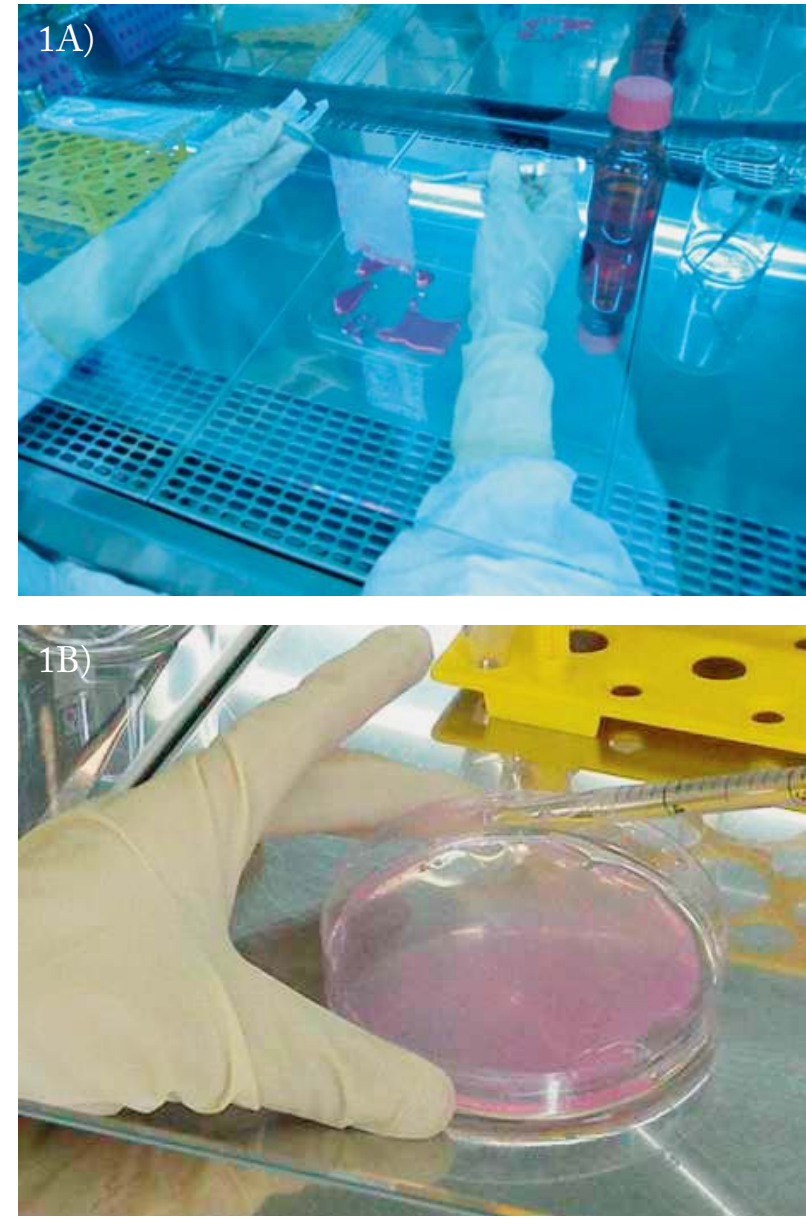

Fig. 1. Cultured epithelial autografts (Rheinwal and Green method) (A) and skin equivalent on fibrin scaffold (B) ready for clinical application.

negative charge of cell culture plastic for adherent cells, nonadherent variant of tissue plastic was used. Fibroblast growth medium was added after fibrin gel polymerization. Fibroblast cultures were kept in incubator at $37{ }^{\circ} \mathrm{C}, 5 \% \mathrm{CO}_{2}$. When fibroblasts in fibrin gel reached $80 \%$ of confluence, keratinocytes without feeder layer were seeded on the top of the gels at a concentration of $40000 \mathrm{cells} / \mathrm{cm}^{2}$. Keratinocyte growth medium was supplemented with tranexamic acid (Cyklokapron, Pfizer, Karlsruhe, Germany) to prevent fibrinolysis of gel by growing cells. Medium was changed every third day. For clinical application, gels at 70\%-90\% of keratinocyte confluence were delivered to the operation room in sterile Petri dishes with serum free medium without tranexamic acid (Fig. 1b). For viability tests, scanning electron microscope 
(SEM) and immunocytochemistry analysis, fibroblasts and keratinocytes were cultured individually, as described below, on fibrin scaffold.

\section{Viability of cells cultured on fibrin scaffold}

Normal human fibroblasts from 9 donors were seeded at a concentration of 100000 cells/well on fibrin gels (as described previously) and in 96-well tissue culture plastic plates for adherent cultures. Cells were cultured for 4 days in fibroblast growth medium. Normal human keratinocytes from 9 donors were seeded at a concentration of 15000 cells/well with irradiated 3T3 feeder layer (1:1 ratio in 96 well-plate on fibrin gel and on tissue culture plastic for adherent cultures). Cells were cultured for 10 days in keratinocyte growth medium. Twenty $\mu \mathrm{L}$ of CellTiter-Blue (Promega, Madison, WI, USA) reagent was added to 100 $\mu \mathrm{L}$ cell culture medium in each well according to the manufacturer's instructions. After 4-h incubation at $37^{\circ} \mathrm{C}$ and $5 \% \mathrm{CO}_{2}$, metabolically active cells reduced indicator dye resazurin into resorufin, a highly fluorescent product. Nonviable cells rapidly lost their metabolic capacity, did not reduce the indicator dye, and fluorescent signal was not detected. The measured fluorescence was proportional to the number of viable cells. All tests were performed in triplicate. Fluorescent signal was measured by fluorometer (Fluoroskan II, Labsystems, USA) using a set of filters $(544 \mathrm{Ex} / 590 \mathrm{Em})$.

\section{Immunofluorescence}

Human keratinocytes with irradiated feeder layer of 3T3 cells (at a 1:1 ratio) and human fibroblasts were seeded at a concentration of 100000 cells/well on fibrin gels in tissue culture grade glass chamber slides (Becton Dickinson Co., New Jersey, USA). Fibroblast or keratinocyte growth medium was changed every third day. Indirect immunocytochemistry was performed at $70 \%$ of cell culture confluence. All antibodies were diluted in $1 \%$ bovine serum albumin (BSA) solution in PBS (Sigma Aldrich, St. Louis, Missouri, USA). Cells were fixed for 10 minutes in $4 \%$ paraformaldehyde and permeabilized in $0.1 \%$ Triton X-100 (Sigma Aldrich, St. Louis, Missouri, USA) for 5 minutes. Samples were incubated with primary antibodies for 1 hour at room temperature. For fibroblast staining, primary goat antibody (whole serum) against human vimentin (Sigma Aldrich, St. Louis, Missouri, USA) was used at 1:20 dilution. For keratinocyte staining, monoclonal mouse antibody against human cytokeratine (CK) 19 (clone RCK108, Dako Denmark A/S, Agilent technologies, Santa Clara, USA) was diluted at 1:100. Mouse immunoglobulin (Ig) IgG1 antibody against human involucrin (clone SY5, Sigma Aldrich, St. Louis, Missouri, USA) was prepared at 1:50 dilution. Immunoreactivity of primary antibodies was visualized with secondary antibodies: rabbit anti-goat $\mathrm{IgG}$ fluorescein isothiocyanate (FITC) antibody (Sigma Aldrich, St. Louis, Missouri, USA) at 1:400 dilution or rabbit anti-mouse IgG Alexa Flour 488 (Invitrogen, Carlsbad, California, USA) at 1:1000 dilution. Antibodies were incubated for 30 minutes in dark place at room temperature and counterstained with Propidium Iodide (Sigma Aldrich, St. Louis, Missouri, USA) $20 \mu \mathrm{g} / \mathrm{mL}$ for 5 minutes. Finally, the cells were treated with an antifade reagent (Prolong Antifade kit, Invitrogen, Carlsbad, California, USA) and observed under confocal microscope (TCS SP2 AOBS, Leica, Wetzlar, Germany).

\section{Scanning electron microscope observation of cell cultures}

Human fibroblasts or keratinocytes were seeded on the top of fibrin gels in 24-well culture plate, as described previously. Cells were grown until $80 \%$ of confluence and analyzed with SEM (ESEM Philips XL30, Amsterdam, Netherlands).

\section{Clinical application}

Appropriate covering of burned parts of the body is vital for favorable results. Good preparation of wound bed is mandatory. In this study, the hydrosurgical VERSAJET system was used. This approach enables the surgeon to precisely select, excise and evacuate nonviable tissue, bacteria and contaminants from burned wound using a tissue-preserving technique. After hydrosurgical preparation of deep burn necrotic tissue, wound bed was prepared for Split-Thickness Skin Grafts (STSG), CEA or skin equivalents (Fig. 2). STSG, as valuable transplants of limited quantity in extensive burns, were put on the degree III wound areas with irregular surfaces. CEA were put on the degree IIb-III wound areas with even surfaces and distant margins (the patients' back and legs) and then 

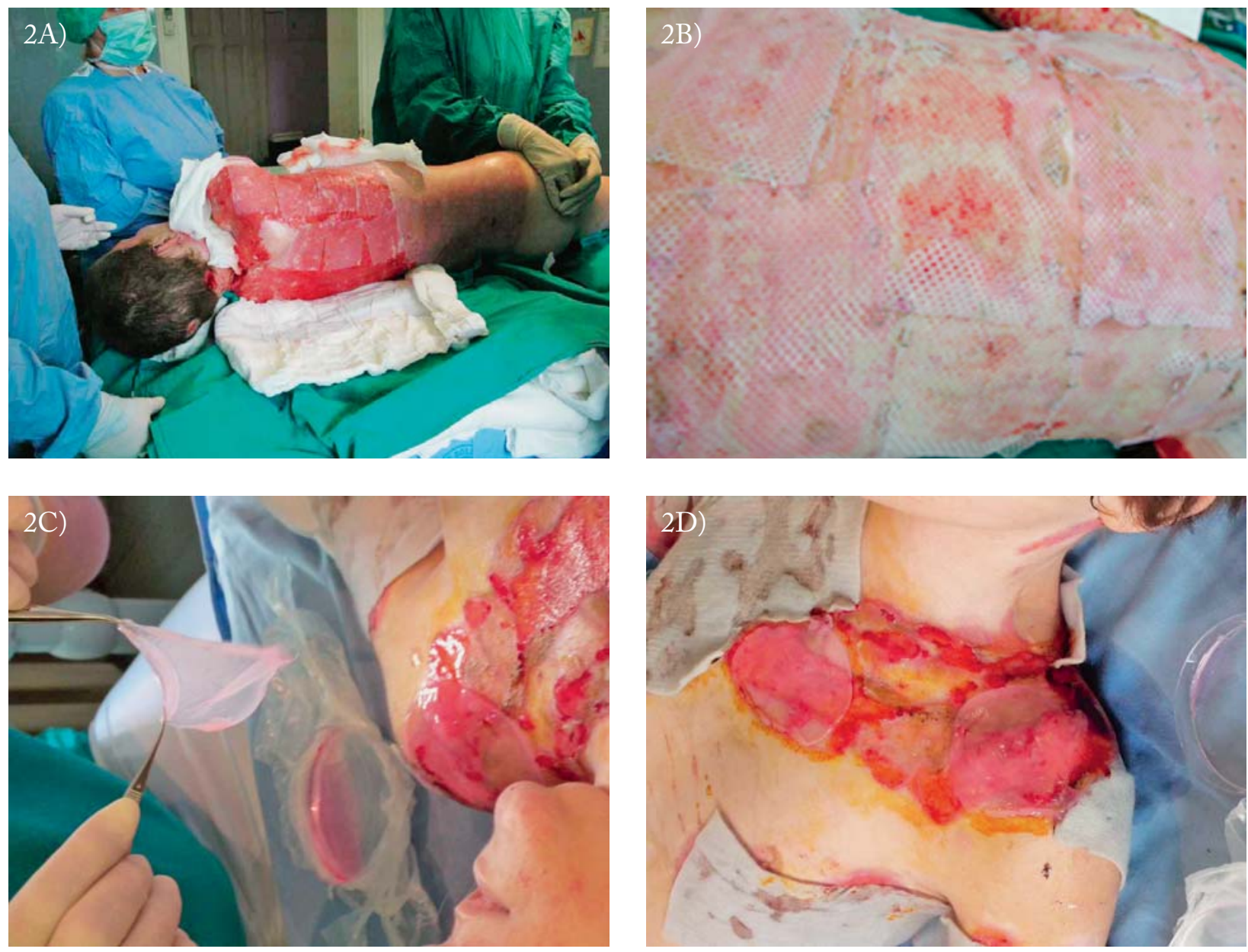

Fig. 2. Grafting of prepared wound bed with cultured epithelial autografts in patient 1 (A) and patient 2 (B), and with skin equivalents on fibrin scaffold in patient $1(C, D)$.

fixed to the surface with surgical staples. Skin equivalents were put on the areas that did not heal after the CEA application (the shoulder and the thigh).

Bacteriological status of the graft bed was monitored at regular intervals. The grafted areas were then covered with surgical non-adherent dressing. Signs of possible bleeding or infection were monitored daily. Dressings were changed twice a week. Progress of the healing was documented using visual estimation (visual estimation of scar height, pliability, surface area, texture, pigmentation, and vascularity) and photos.

\section{Statistical analysis}

Statistical analysis for viability studies was performed using the Statistica 9 (StatSoft Inc., 2010) software. Intensity of resorufin fluorescence was used as a value proportional to the number of viable cells. One-way ANOVA and Tukey post-hoc tests were used. Statistical significance was set at $P<0.05$.

\section{Results}

Cultures were regularly examined using inverted phase-contrast microscope (MBL 3100, A. Krüss Optronic, Germany). In epithelial cultures on feeder layer, keratinocytes had a characteristic polygonal morphology. At lower stage of confluence (Fig. 3a), the supporting feeder layer of sub lethally irradiated mouse 3T3 cells and melanocytes with their dendritic morphology were still visible. Feeder cells, unable to divide, were metabolically active long enough to support growth and proliferation of keratinocytes. As kerati- 


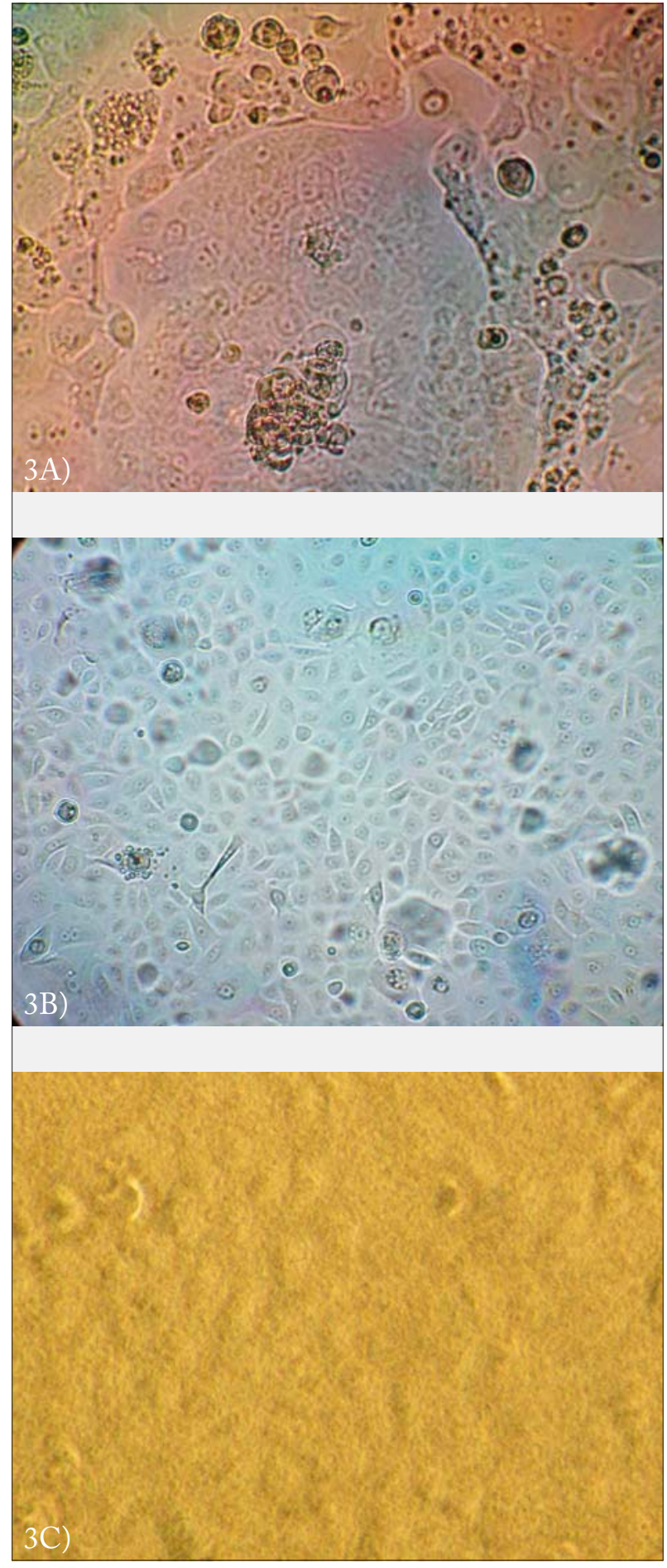

Fig. 3. Human keratinocytes cultured on plastic or fibrin scaffold. Morphology was observed with inverted phase-contrast microscope. Feeder cells were visible at low confluency $(A)$; confluent culture formed multilayered epithelial sheet (B); and fully confluent culture on fibrin scaffold $(C)$.

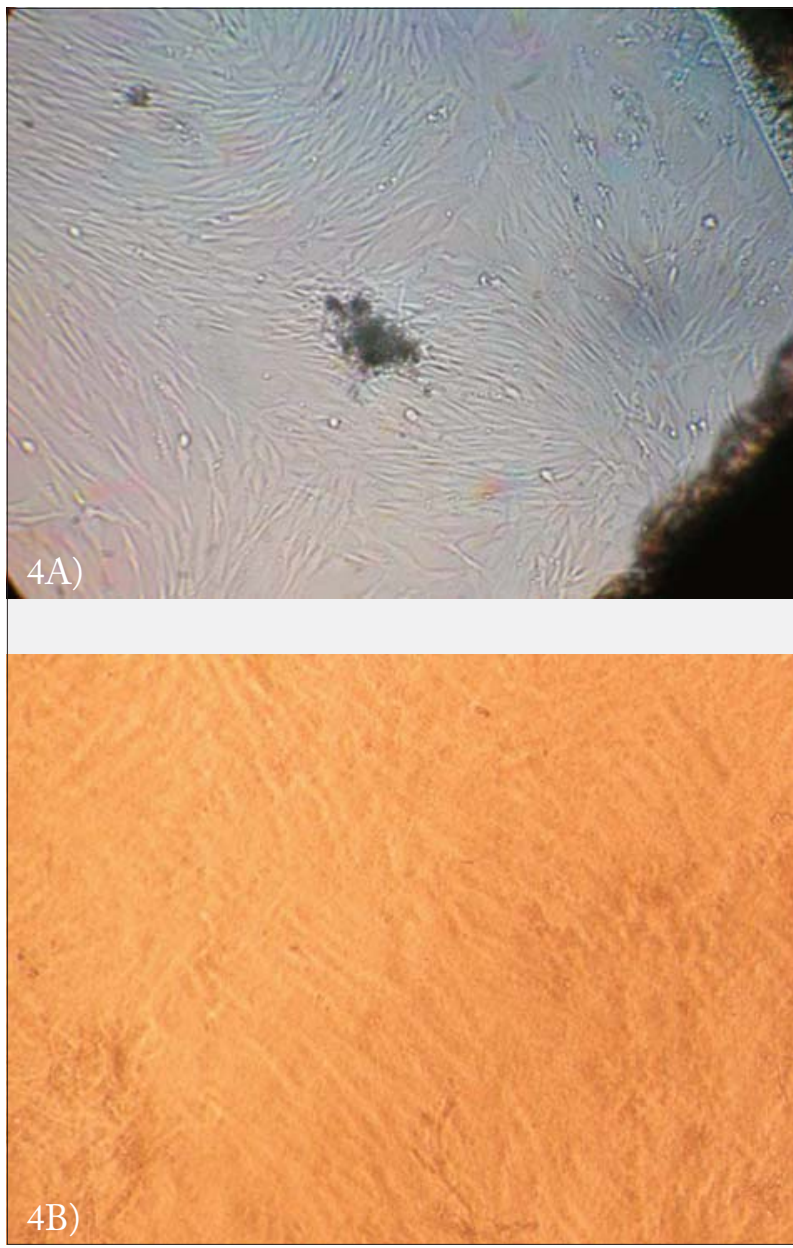

Fig. 4. Human fibroblasts observed with inverted phasecontrast microscope. Cultures at $80 \%$ of confluency on tissue culture plastic (A) and fibrin (B) scaffold.

nocyte colonies spread across the surface of tissue culture vessel, 3T3 cells died. Dead feeder cells were removed from the flask during regular medium change. Fully confluent keratinocyte cultures formed multilayered epithelial sheet ready for harvesting (Fig. 3b). Cultures of dermal fibroblasts showed bipolar spindle morphology (Fig. 4a). Cells cultured on fibrin gel were less visible when compared to those cultured on plastics (Fig. 3c and 4b). SEM images showed good cell attachment and colony spreading of keratinocytes and fibroblasts on fibrin scaffold (Fig. 5).

In CellTiter-Blue test, only metabolically active, viable cells reduced the indicator dye, resazurin into fluorescent resorufin. This product gave measurable fluorescent signal that was proportional to the number of viable 

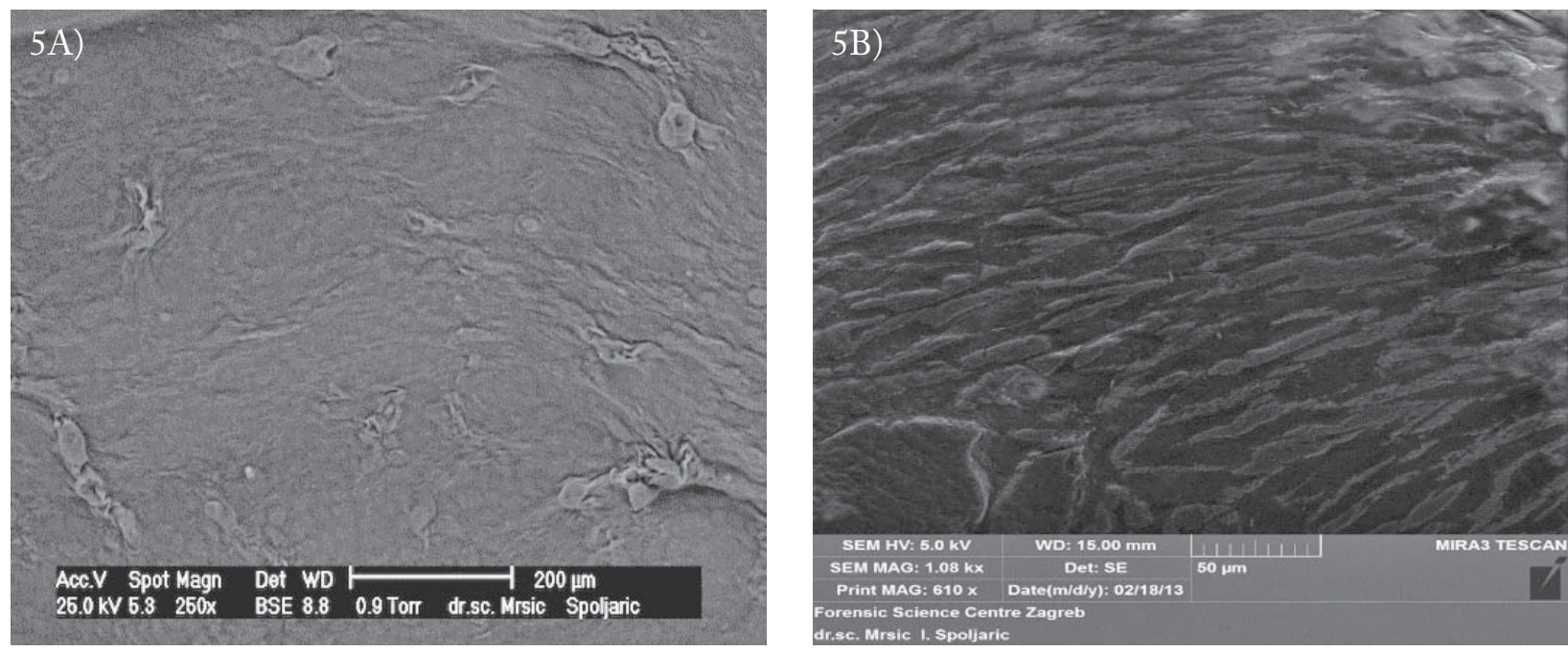

Fig. 5. Scanning electron microscope images of human keratinocytes (A) and fibroblasts (B) grown on fibrin scaffold.
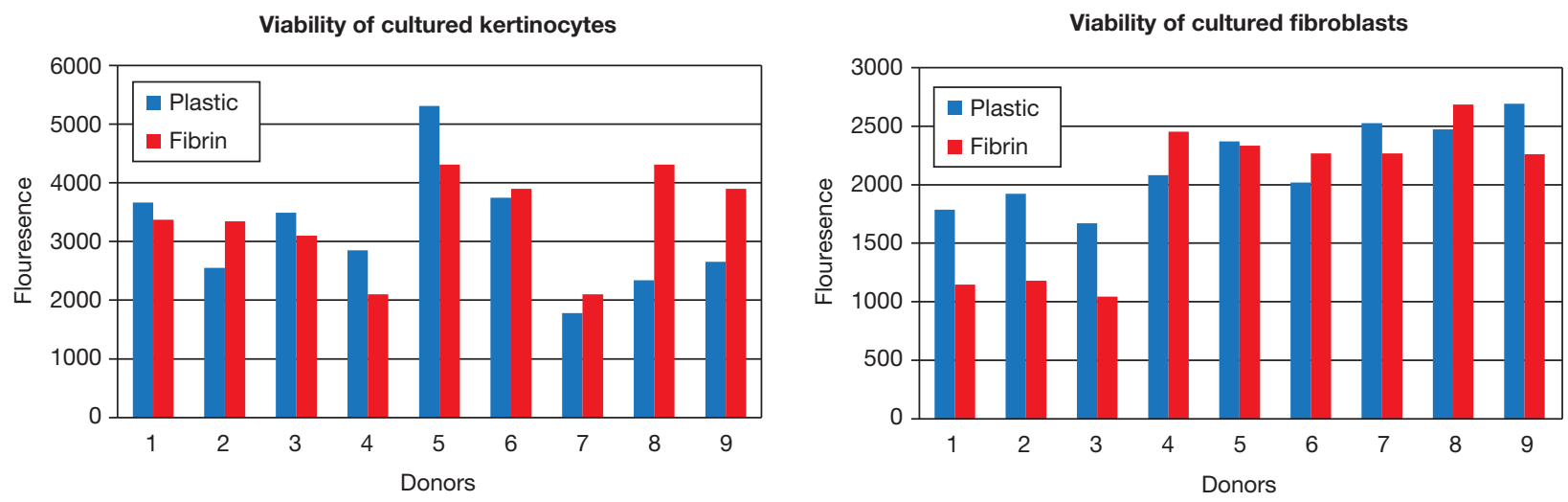

Fig. 6. CellTiter-Blue ${ }^{\circledR}$ Assay of human keratinocytes $(A)$ and fibroblasts $(B)$ of nine donors, cultured on fibrin scaffold and tissue culture plastic. Fluorescence intensity is proportional to cell viability.

cells. Human keratinocytes and fibroblasts proliferated well on both surfaces (Fig. 6). Statistical analysis using One-way ANOVA and Tukey post-hoc tests showed no significant difference in terms of cell viability between tissue culture plastic and fibrin scaffold $(P>0.05)$.

Immunofluorescent staining of keratinocyte cultures on fibrin scaffold showed expression of CK19 (marker of epithelial stem cells) and involucrin (marker of differentiated keratinocytes) (Fig. 7). Fibroblast cultures were identified based on vimentin expression (Fig. 8) ${ }^{25}$. Clinical results clearly showed that appearance of the skin did not differ significantly from the areas of transplantated skin using STSG techniques or CEA. The epidermis was undistinguishable from normal epidermis.

\section{Discussion}

For more than 30 years, CEA have been used in the treatment of heavily burned patients ${ }^{24,26,27}$. Although a great step ahead in regenerative medicine was made, clinical results were not consistent and their application was associated with numerous problems. Reports on CEA take greatly vary from $15 \%$ to $85 \%$. Better results were achieved in those burns with proper wound bed preparation, which could be further enhanced by the presence of some kinds of dermal elements ${ }^{27}$. One of the major problems associated with the production of CEA is long cultivation time to get confluent, 'ripe' multilayered epithelial sheets that can be detached from tissue culture vessels. Meanwhile, 

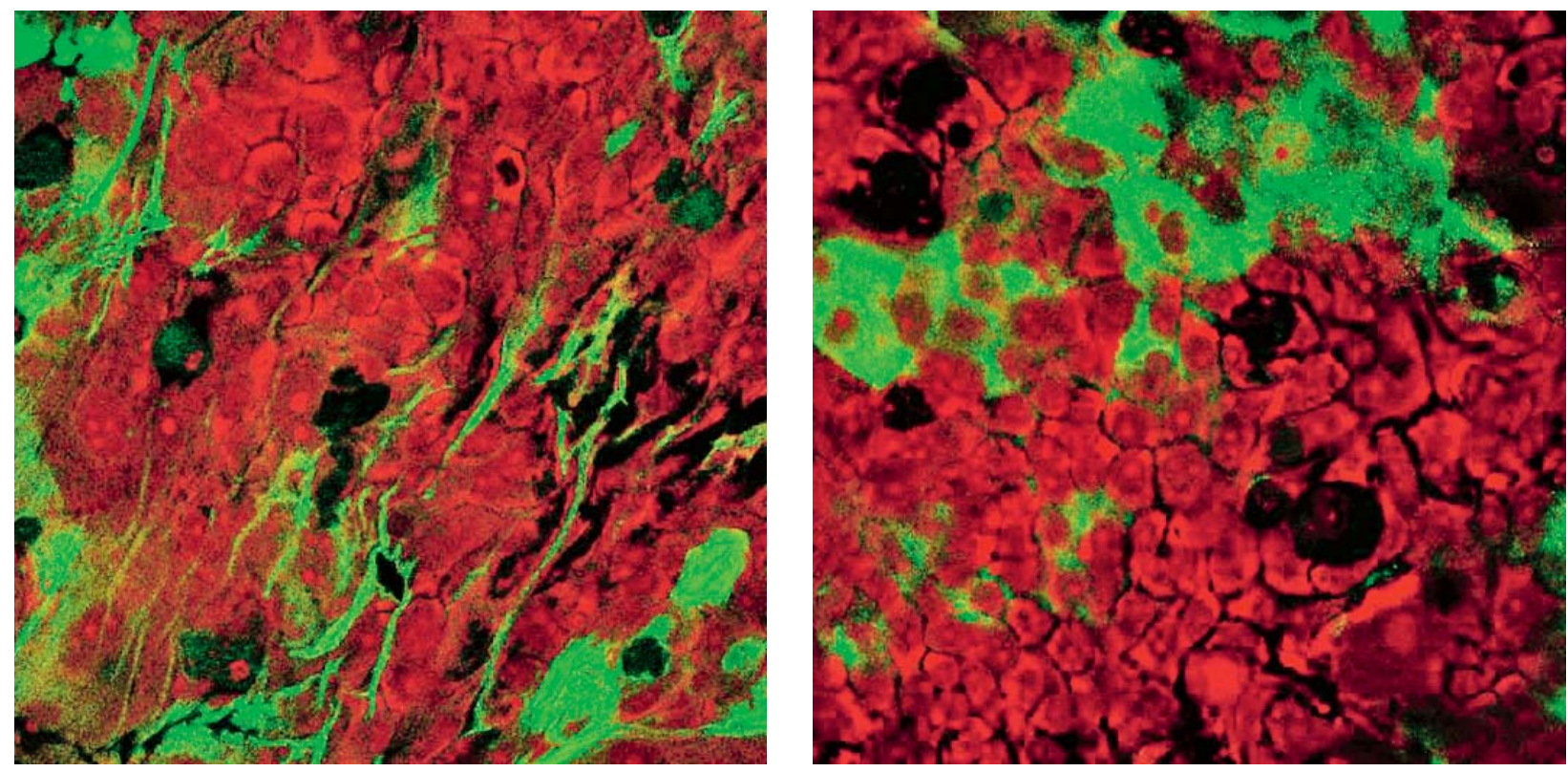

Fig. 7. Immunofluorescent staining of human keratinocytes cultured on fibrin scaffold. Cells were positive for cytokeratin $19(A)$ and involucrin $(B)$.

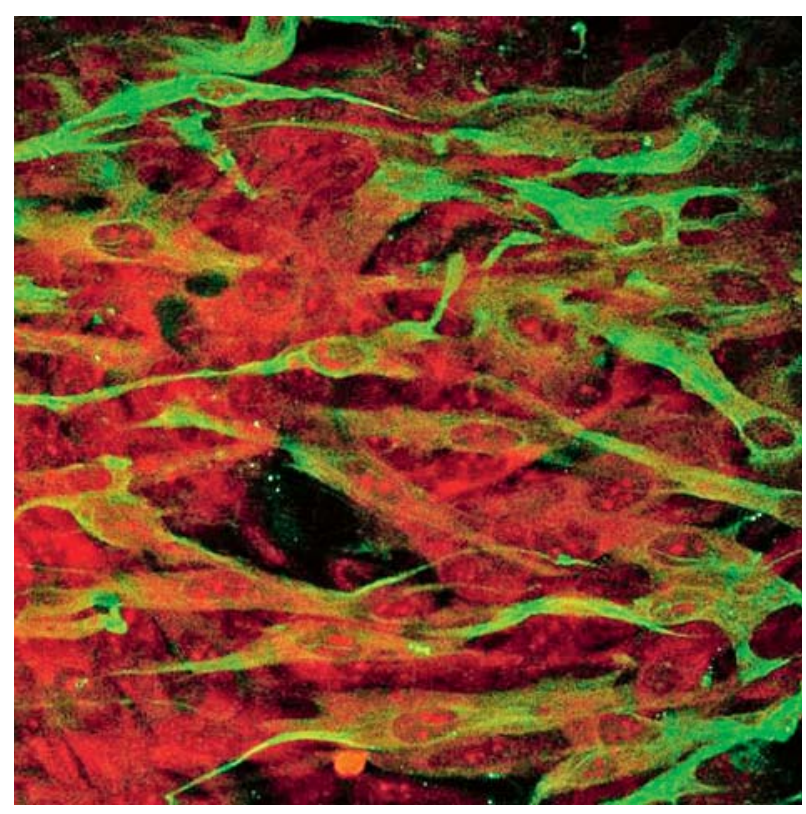

Fig. 8. Immunofluorescent staining of human fibroblasts cultured on fibrin scaffold. Cells were positive for vimentin.

wounds must be covered with temporary substitutes. The enzyme dispase was used for detachment of a CEA sheet. Unfortunately, dispase treatment may also impair keratinocyte attachment to the wound bed due to the loss of intergin $6 ß 4$ expression and changes in basement protein expression ${ }^{28,29}$. In confluent sheets, more keratinocytes are induced to exit highly proliferative state and enter the irreversible process of terminal differentiation. In terminal differentiation, their colony forming efficiency is considerably lower ${ }^{30}$. Some of these problems could be minimized by using cultured skin substitutes that contain both epidermal and dermal components cultured on proper scaffold. Bearing this in mind, cultured skin substitutes on fibrin scaffold were cultivated. Cells were cultured until $80 \%$ of confluence and then transplanted to the patient. The use of subconfluent cells enables more flexible planning of clinical application, and better adaptation to patient's needs. These substitutes are easy to manipulate, flexible, transparent and adhere well to the wound bed.

Inverted phase contrast and SEM images of fibroblasts and keratinocyte cultures on fibrin gel showed typical cell morphology and even cell distribution along the scaffold surface. Immunofluorescence analysis pointed out that keratinocyte cultures on fibrin contained mixed population of cells with the portion of stem cell like cells positive to CK19. CK19, a fibrous protein localized on epidermis and hair follicles, and may be used as a marker for skin and hair follicle 

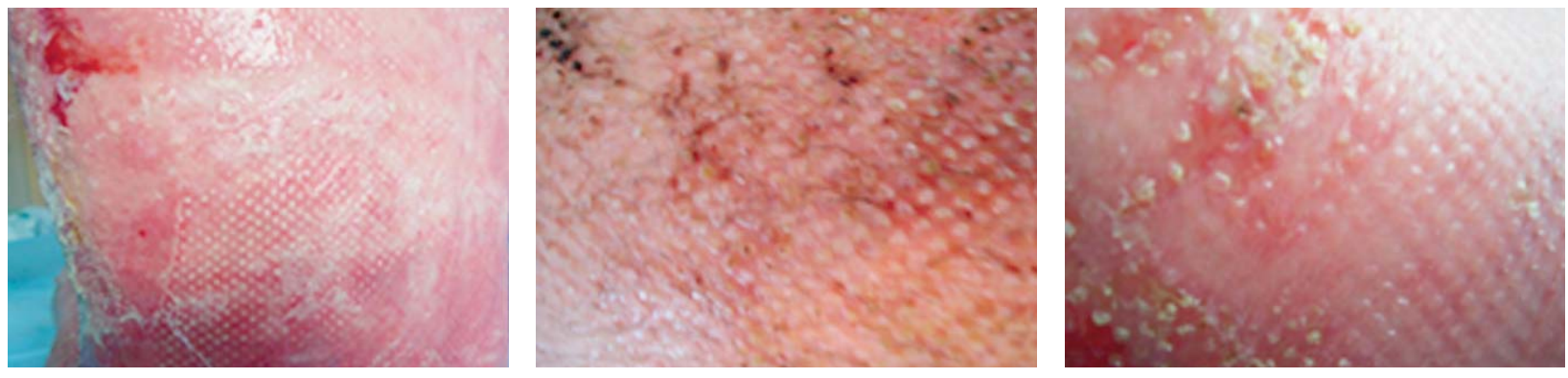

Fig. 9. Appearance of transplanted area 30 days after grafting of skin equivalents in patient 2.
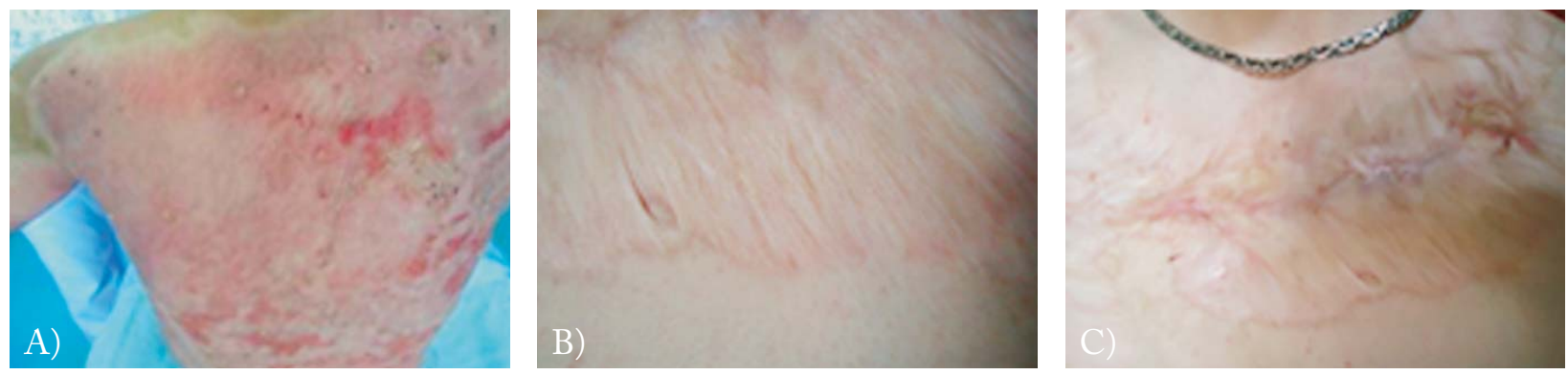

Fig. 10. Transplanted areas after healing with cultured epithelial autografts $(A)$ and skin equivalents in patient $1(C, D)$.

stem cell involved in the regeneration and restoration of skin and growth. This indicated a high proliferative capacity of cell cultures ${ }^{30}$. Presence of differentiated keratinocytes was detected with involucrin ${ }^{2}$. The results of this study were in corcordance with the study of Pellegrini et al. ${ }^{17}$.

When primary cultures of normal cells are cloned, three types of colony grow, called holoclones, meroclones and paraclones. Holoclones are derived from stem cells capable of extensive proliferation and selfrenewal. Early stage transit-amplifying cells form meroclones with limited proliferative capacity and no ability of self-renewal. Paraclones consist of late stage transit-amplifying cells, incapable of further proliferation $^{24}$. Pellegrini et al. used the same method of fibrin scaffold preparation as in this study. They showed normal relative percentages of keratinocyte holoclones, meroclones and paraclones during cultivation on fibrin gel. Moreover, they also proved that keratinocytes preserved their clonogenic ability, growth rate and longterm proliferation potential of the graft ${ }^{17}$.

We have to emphasize that we detected cultured fibroblasts in fibrin gel based on vimentin expression ${ }^{7}$. Keratinocyte and fibroblast viability on plastic and fibrin scaffold was very similar, without statistically significant differences. In clinical application, our results using skin equivalents did not show more frequent local incidence of scar formation as compared to 'classic' techniques of STSG skin grafting (Figs. 9 and 10). These data are highly consistent with other studies ${ }^{16-21}$.

Unlike classic CEA, skin substitutes with fibrin gel are easier to apply in periarticular body portions, i.e. on uneven body surfaces surrounding movable joints, owing to the fact that the fibrin component of the skin substitute glues the graft and no additional staples are necessary.

In conclusion, using fibrin-cultured skin substitutes on massive full-thickness burn will result in good healing (Fig. 10) over up to 3-year follow up.

\section{Acknowledgments}

We thank Igor Špoljarić from Ivan Vučetić Center for Forensic Investigations, Research and Expertise and Lucija Horvat from Ruđer Bošković Institute for their technical support.

\section{References}

1. Mcheik JN, Barrault C, Levard G, Morel F, Bernard FX, Lecron JC. Epidermal healing in burns: autologous keratinocyte transplantation as a standard procedure: update and perspective.Plast Reconstr Surg Glob Open. 2014 Oct 7;2(9):e218.,doi: 10.1097/GOX.0000000000000176. eCollection 2014. 
2. Proksch E, Brandner JM, Jensen JM. The skin: an indispensable barrier. Exp Dermatol. 2008 Dec;17(12):1063-72. PMID: 19043850

3. Ma DR, Yang EN, Lee ST. A review: the location, molecular characterisation and multipotency of hair follicle epidermal stem cells. Ann Acad Mes Singapore. 2004 Nov;33(6):784-8.

4. Levy V, Lindon C, Zheng Y, Harfe BD, Morgan Ba. Epidermal stem cells arise from the hair follicle after wounding. FASEB J. 2007 May;21(7):1358-66. Epub 2007 Jan 25.

5. Lorenz HP, Longaker MT. Wounds: biology, pathology, and management surgery. In: Norton, J, Bollinger RR, Chang, AE, Lowry SF, Mulvihill SJ, Pass HI, Thompson RW, Li M (Eds.). Essential Practice of Surgery, Basic Science and Clinical Evidence. Springer, New York; 2003. p. 77-88.

6. Wong T, McGrath JA, Navsaria H. The role of fibroblasts in tissue engineering and regeneration. Br J Dermatol. 2007;156 (6):1149-55.

7. Sorrell JM, Caplan AI. Fibroblast heterogeneity: more than skin deep. J Cell Sci. 2004 Feb 15;117(Pt 5):667-75.

8. MacNeil S. Progress and opportunities for tissue-engineered skin. Nature. 2007 Feb 22;445(7130):874-80.

9. Zhong SP, Zhang YZ, Lim CT. Tissue scaffolds for skin wound healing and dermal reconstruction. Wiley Interdiscip Rev Nanomed Nanobiotechnol. 2010 Sep-Oct;2(5):510-25., doi: 10.1002/wnan.100.

10. Metcalfe AD, Ferguson MW. Tissue engineering of replacement skin: the crossroads of biomaterials, wound healing, embryonic development, stem cells and regeneration. J R Soc Interface. 2007 Jun 22;4(14):413-37.

11. Laurens N, Koolwijk P, De Maat MP. Fibrin structure and wound healing. J Thromb Haemost. 2006 May;4(5):932-9.

12. Ahmed TA, Dare EV, Hincke M. Fibrin: a versatile scaffold for tissue engineering applications. Tissue Eng Part B Rev. 2008 Jun;14(2):199-215., doi: 10.1089/ten.teb.2007.0435.

13. Currie LJ, Sharpe JR, Martin R. The use of fibrin glue in skin grafts and tissue-engineered skin replacements: a review. Plast Reconstr Surg. 2001 Nov;108(6):1713-26.

14. Hunyadi J, Farkas B, Bertényi C, Oláh J, Dobozy A. Keratinocyte grafting: a new means of transplantation for full-thickness wounds. J Dermatol Surg Oncol. 1988 Jan;14(1):75-8.

15. Horch RE, Bannasch H, Kopp J, Andree C, Stark GB. Singlecell suspensions of cultured human keratinocytes in fibrin-glue reconstitute the epidermis. Cell Transplant. 1998 May-Jun;7 (3):309-17.

16. Ronfard V, Broly H, Mitchell V, Galizia JP, Hochart D, Chambon $\mathrm{E}$, et al. Use of human keratinocytes cultured on fibrin glue in the treatment of burn wounds. Burns. 1991 Jun;17(3):181-4.

17. Pellegrini G, Ranno R, Stracuzzi G, Guerra L, Zambruno G, Micali $\mathrm{G}$, et al. The control of epidermal stem cells (holoclones) in the treatment of massive full-thickness burns with autologous keratinocytes cultured on fibrin. Transplantation. 1999 Sep 27;68(6):868-79.
18. Meana A, Iglesias J, Del Rio M, Larcher F, Madrigal B, Fresno MF, et al. Large surface of cultured human epithelium obtained on a dermal matrix based on live fibroblast-containing fibrin gels. Burns. 1998 Nov;24(7):621-30.

19. Geer DJ, Swartz DD, Andreadis ST. Fibrin promotes migration in a three-dimensional in vitro model of wound regeneration. Tissue Eng. 2002 Oct;8(5):787-98.

20. Hojo M, Inokuchi S, Kidokoro M, Fukuyama N, Tanaka E, Tsuji $\mathrm{C}$, et al. Induction of vascular endothelial growth factor by a fibrin as dermal substrate for cultured skin substitutes. Plast Reconstr Surg. 2003 Apr 15;111(5):1638-45.

21. Mazlyzam AL, Aminuddin BS, Fuzina NH, Norhayati MM, Fauziah O, Isa MR, et al. Reconstruction of living bilayer human skin equivalent utilizing human fibrin as a scaffold. Burns. 2007 May;33(3):355-63. Epub 2007 Feb 26.

22. Sese N, Cole M, Tawil B. Proliferation of human keratinocytes and cocultured human keratinocytes and fibroblasts in threedimensional fibrin constructs. Tissue Eng Part A. 2011 Feb;17(3-4):429-37., doi: 10.1089/ten.TEA.2010.0113. Epub 2011 Jan 13.

23. Kamolz LP, Luegmair M, Wick N, Eisenbock B, Burjak S, Koller R, et al. The Viennese culture method: cultured human epithelium obtained on a dermal matrix based on fibroblast containing fibrin glue gels. Burns. 2005 Feb;31(1):25-9.

24. Rheinwald JG, Green H. Serial cultivation of strains of human epidermal keratinocytes: the formation of keratinising colonies from single cells. Cell. 1975 Nov;6(3):331-43.

25. Kim TK, Kim YJ, Min BH, Kim SJ. The localization of cytokeratin 19 and vimentin in Sprague Dawley albino rat skin tissue. Applied Microscopy. 2014;44:15-20.

26. Boranić M, Jakić-Razumović J, Stanović S, Kljenak A, Fattorini I. Skin cell culture: utilization in plastic surgery and laboratory studies. Lijec Vjesn. 1999 Apr-May;121(4-5):137-43.

27. Atiyeh BS, Costagliola M. Cultured epithelial autograft (CEA) in burn treatment: three decades later. Burns. 2007 Jun;33 (4):405-13. Epub 2007 Apr 2.

28. Poumay Y, Leclercq-Smekens M, Grailly S, Degen A, Leloup R. Specific internalization of basal membrane domains containing the integrin alpha 6 beta 4 in dispase-detached cultured human keratinocytes. Eur J Cell Biol. 1993 Feb;60(1):12-20.

29. Poumay Y, Roland IH, Leclercq-Smekens M, Leloup R. Basal detachment of the epidermis using dispase: tissue spatial organization and fate of integrin alpha 6 beta 4 and hemidesmosomes. J Invest Dermatol. 1994 Jan;102(1):111-7.

30. Harris PA, Leigh IM, Navsaria HA. Pre-confluent keratinocyte grafting: the future for cultured skin replacements? Burns. 1998 Nov;24(7):591-3.

31. Michel M, Török N, Godbout MJ, Lussier M, Gaudreau P, Royal A, et al. Keratin 19 as a biochemical marker of skin stem cells in vivo and in vitro: keratin 19 expressing cells are differentially localized in function of anatomic sites, and their number varies with donor age and culture stage. J Cell Sci. 1996 May;109 (Pt 5):1017-28. 


\section{Sažetak \\ FIBRIN U TKIVNOM INŽENJERSTVU KOŽE - PROIZVODNJA I KLINIČKO ISKUSTVO \\ A. Kljenak, M. Tominac Trcin, M. Bujic, T. Dolenec, M. Jevak, G. Mršic, G. Zmiš, Z. Barčot, A. Muljačić i M. Popović}

Cilj ovoga istraživanja bio je kreirati in vitro nadomjestak ljudske kože s epidermalnim i dermalnim dijelom. Pritom smo koristili fibrinski gel kao nosač stanica. Procijenili smo učinak nadomjestka kože na cijeljenje opeklina drugog i trećeg stupnja. Fibrinski gel načinjen je od komercijalnog kirurškog fibrinskog ljepila. Ljudski fibroblasti kultivirani su u samom fibrinskom nosaču. Ljudski keratinociti zasijani su na gornju površinu nosača. Vijabilnost uzgojenih stanica određena je fluorimetrijski. Nadomjestak kože analiziran je elektronskim skenirajućim mikroskopom. Napravljena je imunocitokemijska analiza kultiviranih stanica. Skenirajući mikroskop pokazao je dobro prianjanje i proliferaciju stanica kože na nosaču. Imunocitokemijska analiza pokazala je prisutnost vimentina, biljega fibroblastnih stanica; citokeratina 19, biljega epitelnih matičnih stanica; te involukrina, biljega diferenciranih keratinocita. Klinička primjena ovih nadomjestaka kože pokazala je slične rezulatate cijeljenja kao i dijelovi rana koji su prekriveni autolognim presatcima kože djelomične debljine. Zaključujemo da nadomjestci kože bazirani na fibrinskom nosaču imaju potencijala u liječenju teških opeklina.

Ključne riječi: Stanice, kultivirane; Fibrin; Koža, umjetna; Opekline 